\title{
Influence of Gasoline Components on Engine Efficiency and Emissions
}

\author{
Guilherme B. Machado ${ }^{1 *}$, José E.M. Barros², Sérgio L. Braga ${ }^{3}$, Carlos Valois M. Braga ${ }^{3}$, \\ Antonio H.M. da F.T. da Silva ${ }^{1}$ and Ellen C.Z. de Azevedo ${ }^{4}$ \\ ${ }^{1}$ Petróleo Brasileiro S.A., Petrobras/Research and Development Center, Av. Horácio Macedo, 950, Cidade Universitária, \\ Iha do Fundão, CEP: 21941-915, Rio de Janeiro, RJ - Brazil \\ 2 Department of Mechanical Engineering, Universidade Federal de Minas Gerais, UFMG, Av. Antonio Carlos, \\ 6627, Campos Universitário, Pampulha, CEP: 31270901, Belo Horizonte, MG - Brazil \\ ${ }^{3}$ Department of Mechanical Engineering, Pontifícia Universidade Católica do Rio de Janeiro, PUC-Rio, \\ rua Marquês de São Vicente, 225, Gávea, CEP: 22453-900, Rio de Janeiro, RJ - Brazil \\ ${ }^{4}$ Consultant, rua Dias da Cruz, 673, Casa 10/101, Meier, CEP: 20720-011, Rio de Janeiro, RJ - Brazil \\ e-mail: machadogb@petrobras.com.br - emautone@terra.com.br \\ slbraga@puc-rio.br -valois@puc-rio.br - ahmfts@petrobras.com.br - ezalona@gmail.com \\ * Corresponding author
}

\begin{abstract}
Résumé - L'influence des composants de l'essence sur l'efficacité et les émissions du moteur - Pour les décennies à venir, il est prévu que les combustibles fossiles et les biocarburants utilisés dans les moteurs à combustion interne restent la principale source de propulsion des véhicules, ce qui justifie la recherche intense dans le monde entier et les efforts de développement pour répondre aux enjeux d'une efficacité croissante et de la réduction des émissions. La modélisation des combustibles commerciaux et les processus de combustion des moteurs présentent de grands défis. Il est également impératif de mieux comprendre comment les différents composants de carburant interagissent et interviennent sur la combustion du moteur et ses paramètres de performance. Dans le travail présenté, des composés représentatifs ont été utilisés afin d'appliquer des méthodologies et d'évaluer l'influence des composants du carburant sur ses propriétés et sur la combustion du moteur, ainsi que sur les paramètres de performance. Une attention toute particulière est accordée à l'efficacité du moteur et au comportement des émissions, de même qu'à leurs corrélations par rapport aux propriétés du carburant et à d'autres paramètres de performance du moteur. Les potentiels de chaque composant et le groupe chimique y afférent ont été identifiés pour différentes définitions techniques moteurs. Les résultats combinent des informations et des méthodologies qui peuvent être utilisées pour développer des carburants destinés à différentes applications.
\end{abstract}

\begin{abstract}
Influence of Gasoline Components on Engine Efficiency and Emissions - For the next few decades, it is expected that fossil fuels and bio-fuels used in internal combustion engines will remain the primary source for vehicular propulsion. This justifies the intense worldwide research and development effort to comply with the challenges of increasing efficiency and reducing internal combustion engine emissions. The modeling of commercial fuels and engine combustion processes presents great challenges. There is also the need to better understand how different fuel components interact and influence engine combustion and performance parameters. In the present work,
\end{abstract}


surrogate fuels were used to implement methodologies to evaluate the influence of fuel components on fuel properties and multiple engine combustion and performance parameters. Special attention is given to engine efficiency and emissions behavior and their correlations to fuel properties and others performance parameters of the engine. The potentials of each component and corresponding chemical group were identified for different engine designs. The results combine information and methodologies that can be used to develop fuels for different applications.

\section{ABBREVIATIONS}

$\begin{array}{ll}\text { A/F ratio } & \text { Air/Fuel ratio } \\ \text { AKI } & \text { Anti-Knock Index } \\ \text { BTDC } & \text { Before piston Top Dead Center } \\ \text { CA } & \text { Crank Angle } \\ \text { CFR } & \text { Cooperative Fuel Research or code of } \\ & \text { federal regulations } \\ \text { CO } & \text { Carbon monoxide } \\ \text { CO } 2 & \text { Carbon dioxide } \\ \text { E } & \text { Anhydrous ethanol } \\ \text { ECU } & \text { Electronic Control Unit } \\ \mathrm{HC} & \text { Hydrocarbons } \\ \mathrm{H} / \mathrm{C} & \text { Hydrogen/carbon molar ratio } \\ \mathrm{ICE} & \text { Internal Combustion Engine } \\ \mathrm{IO} & \text { Iso-octane } \\ \text { LHV } & \text { Lower Heating Value } \\ \mathrm{MBT} & \text { Maximum Break Torque } \\ \mathrm{MON} & \text { Motor Octane Number } \\ \mathrm{NH} & \text { N-heptane } \\ R & \text { Correlation factor } \\ \text { RON } & \text { Research Octane Number } \\ \mathrm{SI} & \text { Spark Ignition } \\ \mathrm{T} & \text { Toluene } \\ \mathrm{T} 50 \% & \text { Temperature at } 50 \% \text { v/v of fuel distilled } \\ \mathrm{WOT} & \text { Wide Open Throttle } \\ & \end{array}$

\section{INTRODUCTION}

Gasoline is a complex mixture that has a quasicontinuous spectrum of hydrocarbon constituents. Surrogate fuels that decrease the chemical and/or physical complexity of gasoline can be used to enhance the understanding of fundamental processes involved in the interaction between fuels and Internal Combustion Engines (ICE). Pitz et al. (2007) have presented an extensive review about surrogate fuels that describes all of the possible components, their importance and the availability of physical and thermochemical data. These studies indicate that $n$-heptane, iso-octane and toluene are interesting components to model gasoline properties in surrogate fuels. Several studies in the literature examined the kinetic models of iso-octane (Curran et al., 2002; Davidson et al., 2005; He et al., 2005), n-heptane (Curran et al., 1998; Herzler et al., 2005; Berta et al., 2006; Gauthier et al., 2004; Silke et al., 2005) and toluene (Davidson et al., 2005; Bounaceur et al., 2005; Dagaut et al., 2002; Emdee et al., 1992; Pitz et al., 2003; Sivaramakrishnan et al., 2005). For example, Andrae (2008) presented a detailed kinetic model that describes the autoignition of surrogate fuels consisting of iso-octane, $n$-heptane, toluene, diisobutylene and ethanol. These studies were based on experiments conducted at different pressures and temperatures, and in different environments, including shock tubes, rapid compression machines and constant volume chambers. The experiments were conducted to reproduce various thermodynamic conditions that represent different engine operating conditions.

In the literature, the authors found few direct correlations between surrogate fuel behavior in basic controlled experiments using shock tubes and rapid compression machines and the ability of surrogate fuels to reproduce gasoline performance in commercial SI engines. The behavior of surrogate fuels in a modern commercial ICE is not well understood.

Machado (2012) and Machado et al. (2011) presented the ability of surrogate fuels composed of iso-octane, $n$-heptane, toluene and ethanol to reproduce the performance of full Brazilian gasoline in commercial engines. These studies determined the optimal amount of each component in a surrogate fuel for high-octane oxygenated gasolines. It is important to mention that regular Brazilian gasoline contains 18 to $25 \%$ anhydrous ethanol by volume, which is required by law and varies depending on ethanol production and international market conditions (ANP, 2011). Machado (2012) and Machado et al. (2012) investigated the effect of individual components of surrogate fuels on fuel properties and commercial engine performance. That study led to the introduction of methodologies for fuel development based on response surface models derived from experimental design and engine tests. The present paper presents further results, and gives special attention to the influence of fuel components and properties on engine efficiency and emissions. 


\section{METHODOLOGIES}

The methodologies for surrogate fuels selection, engine test cell preparation and experimental procedures are described in more details in Machado (2012) and Machado et al. $(2011,2012)$. The main points are summarized in the next sections.

\subsection{Fuel Components Concentrations}

Based on a mixture design approach, ten gasoline surrogate fuels were prepared with different concentrations of iso-octane (IO), $n$-heptane (NH) and toluene (T). Anhydrous ethanol (E) was incorporated into all of the mixtures at a fixed volume concentration of $25 \%$. Table 1 lists the original volume concentration of each component in the surrogate fuels. In Section 2, the surrogate fuels are represented in ternary diagrams according to the volume fraction of each component normalized with respect to the surrogate fuel in the absence of ethanol (Fig. 1).

In this work, no runs were done with pure iso-octane, $n$-heptane or toluene in blends with ethanol. These additional runs could make results extrapolations more reliable and is a suggestion for future works. However, the mixture of $n$-heptane in blend with $25 \%$ of ethanol could present running problems in several engine operating conditions due to the very low octane rating of the fuel.

TABLE 1

Original concentrations of each component

\begin{tabular}{c|c|c|c|c}
\hline \multirow{2}{*}{ Fuel } & \multicolumn{4}{|c}{ Volume concentration (\%) } \\
\cline { 2 - 5 } & $\mathrm{IO}^{\mathrm{a}}$ & $\mathrm{NH}^{\mathrm{b}}$ & $\mathrm{T}^{\mathrm{c}}$ & $\mathrm{E}^{\mathrm{d}}$ \\
\hline $\mathrm{B}$ & 25 & 25 & 25 & 25 \\
\hline C & 31.25 & 12.5 & 31.25 & 25 \\
\hline $\mathrm{D}$ & 31.25 & 31.25 & 12.5 & 25 \\
\hline E & 37.5 & 18.75 & 18.75 & 25 \\
\hline F & 18.75 & 37.5 & 18.75 & 25 \\
\hline G & 18.75 & 18.75 & 37.5 & 25 \\
\hline H & 0 & 37.5 & 37.5 & 25 \\
\hline I & 37.5 & 37.5 & 0 & 25 \\
\hline J & 37.5 & 0 & 37.5 & 25 \\
\hline
\end{tabular}

${ }^{\text {a }} \mathrm{IO}$ - Iso-octane,

${ }^{\text {b }} \mathrm{NH}-\mathrm{N}$-Heptane,

${ }^{\mathrm{c}} \mathrm{T}$ - Toluene,

${ }^{\mathrm{d}}$ E - Ethanol.

\subsection{Fuel Properties}

The properties of the surrogate fuels are presented in Table 2 and are within the typical range of ethanol oxygenated gasoline blends. The stoichiometric air/fuel ratio, density and Lower Heating Value (LHV) were calculated based on the C:H:O ratio of each mixture and on the properties of each component combined in a mass base. The T50\% value, temperature at $50 \% \mathrm{v} / \mathrm{v}$ of fuel distilled, was calculated by averaging the results of three different methodologies. The fuels were individually tested in a Cooperative Fuel Research (CFR) engine to determine the values of MON and RON in order to calculate the Anti-Knock Index (AKI), which is the average of both measurements (Machado et al., 2011, 2012; Machado, 2012).

\subsection{Engine Tests}

\subsubsection{Test Cell Preparation}

The engine utilized in this study was the Fiat Fire 1.4L Tetrafuel. This engine can run on pure gasoline, Brazilian gasoline (18 to $25 \%$ anhydrous ethanol by volume), mixtures of Brazilian gasoline and hydrous ethanol or natural gas. The main engine specifications are presented in Table 3.

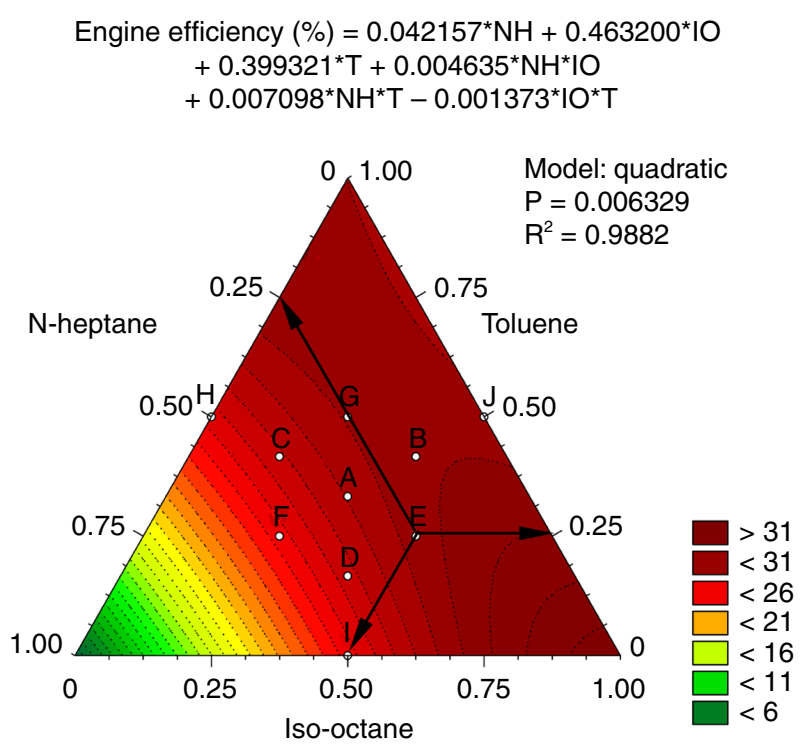

Note: $25 \%$ v/v ethanol

Figure 1

Engine efficiency at $3875 \mathrm{rpm}$ with WOT. 
TABLE 2

Fuel properties

\begin{tabular}{|c|c|c|c|c|c|c|c|}
\hline Fuel & Density $\left(\mathrm{kg} / \mathrm{m}^{3}\right)$ & $\mathrm{LHV}^{\mathrm{a}}(\mathrm{kJ} / \mathrm{kg})$ & 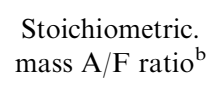 & $\mathrm{T} 50 \%{ }^{\mathrm{c}}\left({ }^{\circ} \mathrm{C}\right)$ & $\mathrm{MON}^{\mathrm{d}}$ & $\mathrm{RON}^{\mathrm{e}}$ & $\mathrm{AKI}^{\mathrm{f}}$ \\
\hline A & 758.3 & 38712 & 13.04 & 97.0 & 86.0 & 95.2 & 90.6 \\
\hline B & 770.2 & 38506 & 12.95 & 97.4 & 90.8 & 103.0 & 96.9 \\
\hline $\mathrm{C}$ & 768.7 & 38531 & 12.95 & 96.6 & 82.2 & 91.2 & 86.7 \\
\hline D & 735.9 & 39117 & 13.22 & 96.6 & 82.6 & 89.0 & 85.8 \\
\hline E & 747.8 & 38898 & 13.12 & 97.4 & 89.4 & 99.0 & 94.2 \\
\hline $\mathrm{F}$ & 746.3 & 38924 & 13.13 & 96.6 & 77.6 & 84.0 & 80.8 \\
\hline G & 780.6 & 38331 & 12.87 & 97.4 & 88.2 & 100.2 & 94.2 \\
\hline $\mathrm{H}$ & 779.1 & 38354 & 12.87 & 96.6 & 78.2 & 87.2 & 82.7 \\
\hline I & 713.6 & 39546 & 13.41 & 96.6 & 77.4 & 82.0 & 79.7 \\
\hline $\mathbf{J}$ & 782.1 & 38307 & 12.86 & 97.4 & 96.0 & 108.0 & 102.0 \\
\hline
\end{tabular}

${ }^{\text {a }}$ LHV - Lower Heating Value,

${ }^{\mathrm{b}} \mathrm{A} / \mathrm{F}$ ratio - Air/Fuel ratio,

c $\mathrm{T} 50 \%$ - Temperature at $50 \% \mathrm{v} / \mathrm{v}$ of fuel distilled,

${ }^{\mathrm{d}}$ MON - Motor Octane Number (average of two tests),

${ }^{\text {e }}$ RON - Research Octane Number (average of two tests),

${ }^{\mathrm{f}}$ AKI - Anti-Knock Index.

TABLE 3

Specifications of the Fiat Fire Tetrafuel engine

\begin{tabular}{c|c}
\hline Swept volume & $1368 \mathrm{~cm}^{3}$ \\
\hline Number of cylinders & 4 in line \\
\hline Cylinder diameter & $72 \mathrm{~mm}$ \\
\hline Stroke & $84 \mathrm{~mm}$ \\
\hline Piston bore & $71.9 \mathrm{~mm}$ \\
\hline Compression ratio & $10.35: 1$ \\
\hline Valves per cylinder & 2 \\
\hline Camshaft & 1 (overhead)
\end{tabular}

The tests were conducted in an engine test cell according to ISO 1585 (ISO, 1992). The original Electronic Control Unit (ECU) of the engine was replaced with a programmable unit to allow for engine spark timing and air/fuel ratio calibration. Cylinder 1 was instrumented with an AVL GU 13Z-24 piezoelectric combustion pressure transducer and an IndiModul 621 data acquisition system for combustion analysis and knocking observations. The occurrence of knocking was further monitored by an audio system.
TABLE 4

Engine operating conditions

\begin{tabular}{c|c|c}
\hline Speed (rpm) & Load (\% throttle position) & Lambda \\
\hline 5500 & 100 & 0.9 \\
\hline 3875 & 100 & 0.9 \\
\hline 3875 & 16 & 1.0 \\
\hline 2250 & 100 & 0.9 \\
\hline 2250 & 16 & 1.0 \\
\hline 1500 & 16 & 1.0 \\
\hline
\end{tabular}

\subsubsection{Experimental Test Procedures}

To cover a wide range of engine operating conditions, the tests were performed at six different operating points (speed and \% throttle position), as shown in Table 4.

Lambda was fixed at a value of 0.9 for full load conditions (Wide Open Throttle - WOT) and 1.0 for partial load conditions (Tab. 4). This approach is justified by the calibration carried out by the engine manufacturers. The calibration is conducted to optimize power at WOT and to reduce emissions during partial load conditions. The lambda value for gasoline to achieve maximum power is typically within the range of 0.88 to 0.92 , while lambda 
to achieve maximum catalyst efficiency and minimal emissions at partial load is 1.0. To maintain a constant lambda at each engine operating point, the tests were performed in a closed loop mode.

For each fuel and engine operating condition (speed and $\%$ throttle position), the spark timing had a different calibration, adjusted to obtain the MBT (Maximum Break Torque), constrained by knocking occurrence and a maximum exhaust gas temperature of $900^{\circ} \mathrm{C}(1173 \mathrm{~K})$. This temperature limit generally preserves emissions control catalysts.

At least three measurements of torque and fuel consumption were performed for each fuel after a one minute engine stabilization period per operating condition.

\subsubsection{Emissions Measurement}

The emissions measurement was completed using the NAPRO Modal 2010 - AO, which was adapted for the engine test cell. This equipment has nondispersive infrared gas analyzers that perform volumetric measurements of $\mathrm{CO}, \mathrm{CO}_{2}$ and $\mathrm{HC}$ in dry base. The catalyst was removed from the engine exhaust pipe to measure the raw emissions. The measurements were performed over at least 40 seconds. At the same time, the torque and fuel consumption measurements were completed. The emission results were reported as the calculated average from the measurement period.

In addition to the analysis of the volumetric emissions, the specific emissions were also calculated in $\mathrm{g} / \mathrm{kWh}$, according to CFR, title 40 (CFR, 2009; Melo et al., 2012; Machado, 2012).

\subsection{Data Reduction}

The influences of the different fuel components on the fuel properties and engine performance were compared by adopting the mixture design approach for typical Brazilian gasoline/ethanol $75 / 25 \%$ vol/vol blends. Response surfaces were statistically determined based on normalized factors (normalized concentrations of the components), and mathematical models were developed based on original factors using STATISTICA ${ }^{\circledR}$ software (Montgomery and Runger, 1994; Calado and Montgomery, 2003). Therefore, the mathematical models presented in the next sections, including the corresponding ternary plots of response surfaces, are based on the volume percent concentration of each component in the original mixture (Tab. 1). The mathematical models presented are more accurate in the regions near the experimental data points. The extrapolations (regions near the vertices of the domain) are also important for exploring general tendencies. Some of the figures present quadratic models that include the existence of terms that reflect interactions among different components. It is important to point out that the mathematical models were the result of a multiparametric regression analysis associated with highly sensitive statistical significance test methodologies. Each response surface presented has an associated correlation factor $\left(R^{2}\right)$ and a $p$ factor, relative to the statistical significance level of the model. To guarantee 95\% model confidence, only models with $p \leq 0.05$ were considered. It should be noted that the ternary diagrams have a particular reading procedure, as illustrated in Figure 1. The concentration readings of the components on the ternary diagrams should be multiplied by $75 \%$ to obtain the original concentration used in the mathematical models presented.

The models were developed from average data. The maximum uncertainty for all of the variables with all of the fuels and engine operating conditions was $0.6 \%$. The uncertainties were calculated combining type A and type B uncertainties, respectively related to the statistical random uncertainties present in individual measurements and instrumentation uncertainties. A coverage factor of 2 was used to guarantee $95 \%$ of confidence level (Machado, 2012).

\section{RESULTS AND DISCUSSION}

This section presents the results and analyses of the influence of fuel components and properties on overall engine efficiency, combustion efficiency and emissions. The trends observed for the different parameters evaluated are always similar for more than one operating condition. In each case, only one engine condition is shown to represent the general behavior of the parameter analyzed.

\subsection{Influence of Fuel Components and Properties on Engine Efficiencies}

The engine was operated successfully using each of the surrogate fuels tested. This section presents results for the overall engine efficiency and the combustion efficiency. It is important to note that for the engine and operating conditions evaluated in this work (Tab. 4), $5500 \mathrm{rpm}$ with WOT, $3875 \mathrm{rpm}$ with WOT, 2250 rpm with WOT and $1500 \mathrm{rpm}$ with partial load were the conditions susceptible to knocking. In contrast, $3875 \mathrm{rpm}$ with partial load and $2250 \mathrm{rpm}$ with partial load did not demonstrate any susceptibility to knocking with any of the fuels tested. 


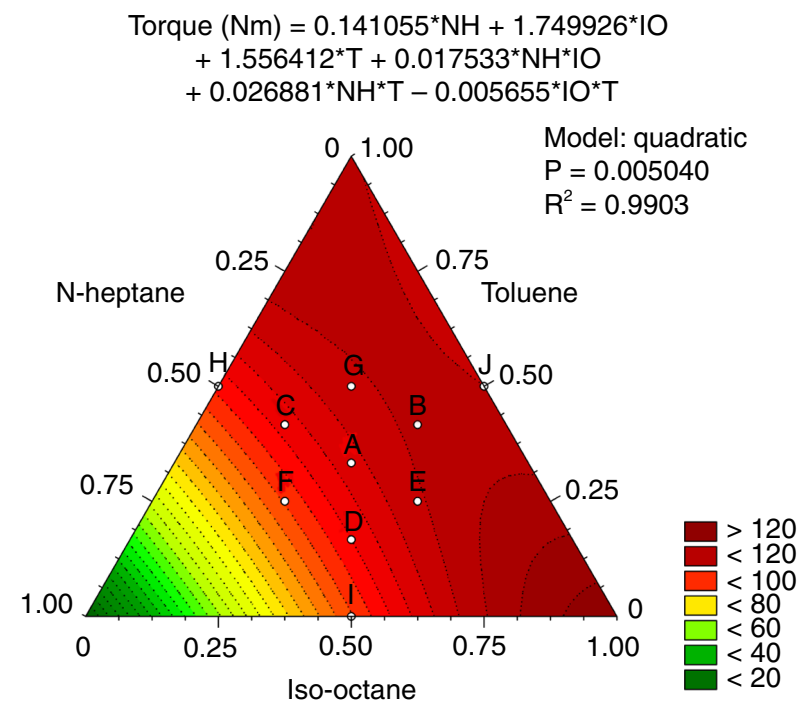

Note: $25 \%$ v/v ethanol

Figure 2

Engine torque at $3875 \mathrm{rpm}$ with WOT.

\subsubsection{Overall Engine Efficiency}

Several different efficiency types are studied when analyzing engine performance. The overall engine efficiency analyzed here is the ratio of the brake power to the energy flow rate delivered to the engine. The energy flow rate to the engine is the product of the fuel consumption and the LHV (fuel Lower Heating Value).

Statistically significant response surface models were obtained for all of the operating conditions with the exception of the $3875 \mathrm{rpm}$ with partial load condition. This condition had a lower efficiency, and it was difficult to distinguish differences between the fuels.

For all of the operating conditions sensitive to knocking there was good agreement between overall engine efficiency and the torque, as shown in Figures 1 and 2, which represent the operating condition of $3875 \mathrm{rpm}$ with WOT.

For surrogate fuels with higher concentrations of toluene and iso-octane, the higher the torque produced, the higher the resulting overall engine efficiency is. Isooctane proved to be more effective than toluene in increasing the overall engine efficiency. As shown in Figure 3, toluene contributes to an increase in the fuel consumption (lower stoichiometric air/fuel ratio), while iso-octane reduces the fuel consumption (higher stoichiometric air/fuel ratio). The stoichiometric air/fuel ratio is shown in Figure 4.

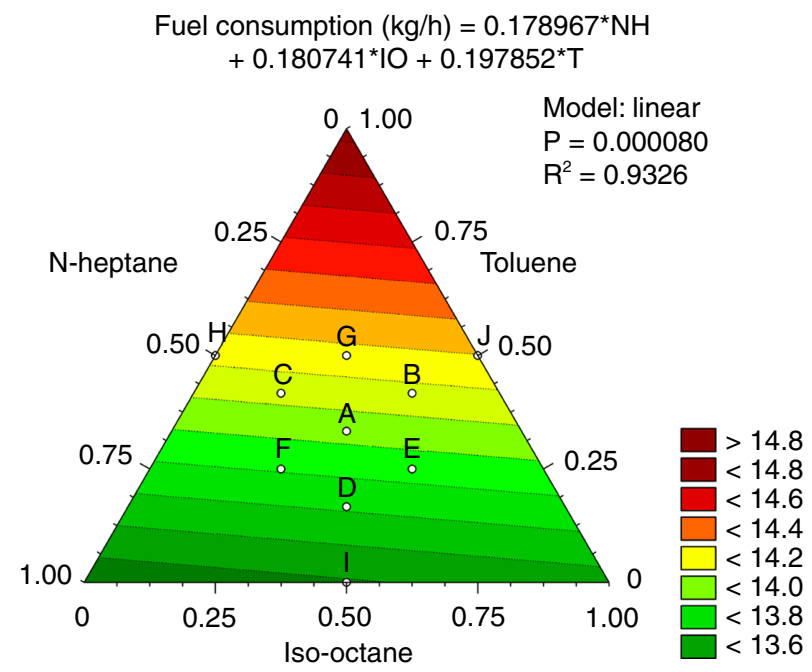

Note: $25 \%$ v/v ethanol

Figure 3

Fuel consumption at $3875 \mathrm{rpm}$ with WOT.

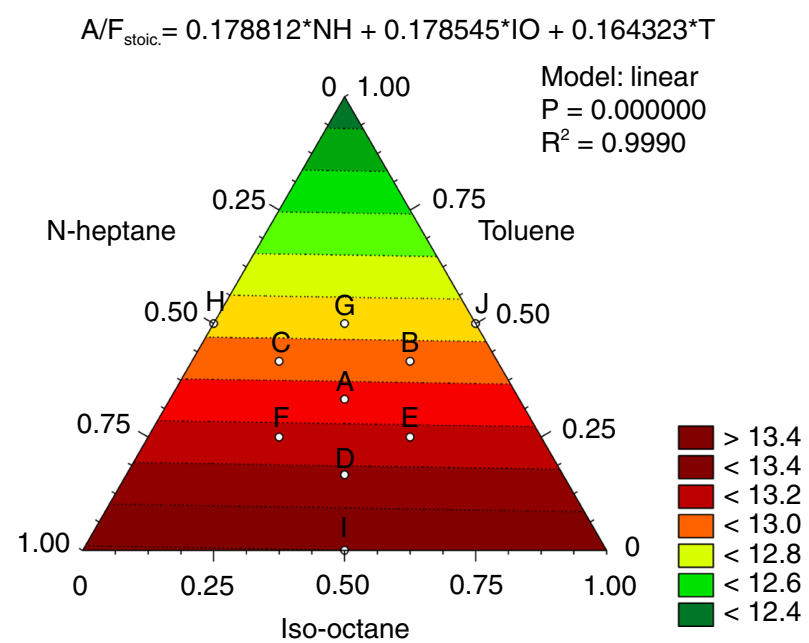

Note: $25 \%$ v/v ethanol

Figure 4

Stoichiometric air/fuel ratio.

The lower value of LHV per $\mathrm{kg}$ of stoichiometric air that is presented in Figure 5 also favors iso-octane for increasing the overall engine efficiency. 


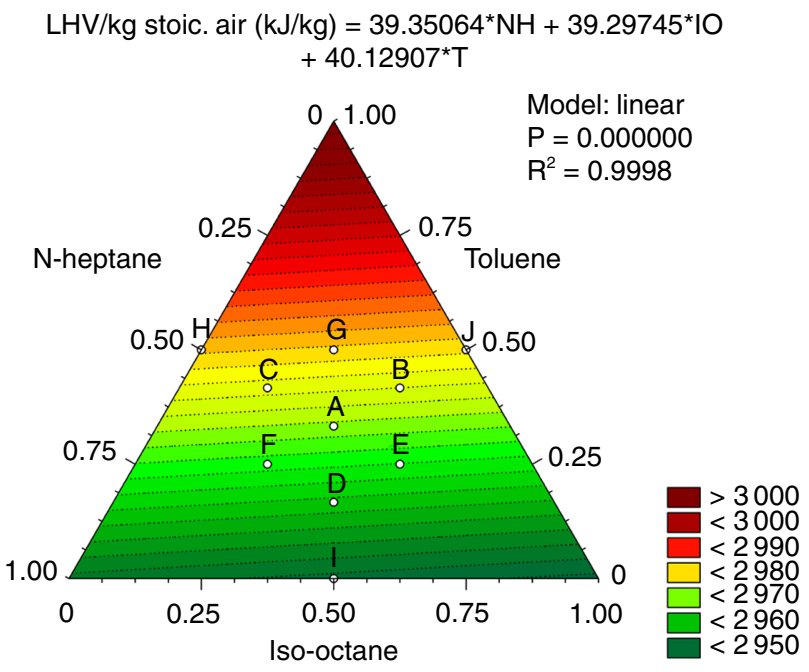

Note: $25 \%$ v/v ethanol

Figure 5

Fuel lower heating value per $\mathrm{kg}$ of stoichiometric air.

For the operating conditions that are sensitive to knocking, it is generally shown that the fuel octane rating (Fig. 6) has a greater impact on the overall engine efficiency (Fig. 1) than the stoichiometric air/fuel ratio (Fig. 4) and the lower heating value per $\mathrm{kg}$ of stoichiometric air (Fig. 5). Figures 1 and 6 show similar trends. The higher the octane rating is, the higher the overall engine efficiency is. This phenomenon is related to more advanced ignition timing calibration, as shown in Figure 7 (negative values indicate BTDC, Before Piston Top Dead Center). Nevertheless, the stoichiometric air/fuel ratio (Fig. 4) and the lower heating value per $\mathrm{kg}$ of stoichiometric air (Fig. 5) contribute to the overall engine efficiency, leading to better performance characteristics with iso-octane compared to toluene.

For the operating conditions that are not sensitive to knocking, there was good agreement between the overall engine efficiency and fuel consumption. This result is clear from the comparison of Figures 8 and 9, which represent the operating condition of $2250 \mathrm{rpm}$ with partial load.

In the conditions that are not sensitive to knocking, the engine torque did not vary significantly between the fuels. Thus, the stoichiometric air/fuel ratio (Fig. 4) becomes a more significant fuel property than the octane rating (Fig. 6) for increasing the overall engine efficiency. This fact can be an important consideration for special applications, such as race fuel formulations, where higher engine speeds do not allow time for knocking and the AKI may not be as relevant.

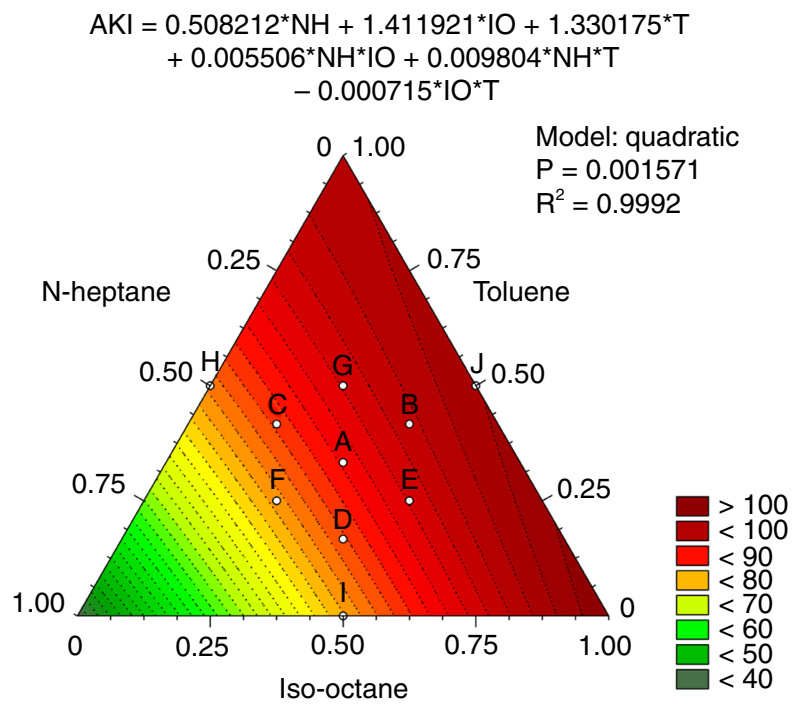

Note: $25 \%$ v/v ethanol

Figure 6

Fuel Anti-Knock Index (AKI).

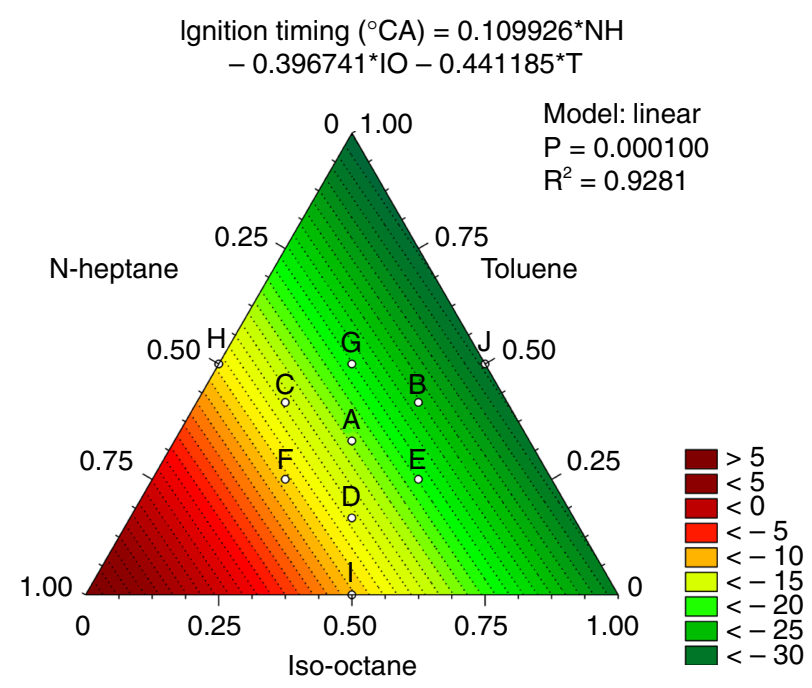

Note: $25 \%$ v/v ethanol

Figure 7

Ignition timing at $3875 \mathrm{rpm}$ with WOT.

It is possible to see that iso-octane was more effective than $n$-heptane in increasing engine efficiency for the $2250 \mathrm{rpm}$ with partial load condition, unlike the behavior observed for the fuel consumption. This occurred because there is a lower value of $\mathrm{LHV}$ per $\mathrm{kg}$ of stoichiometric air of iso-octane compared to $n$-heptane (Fig. 5). 


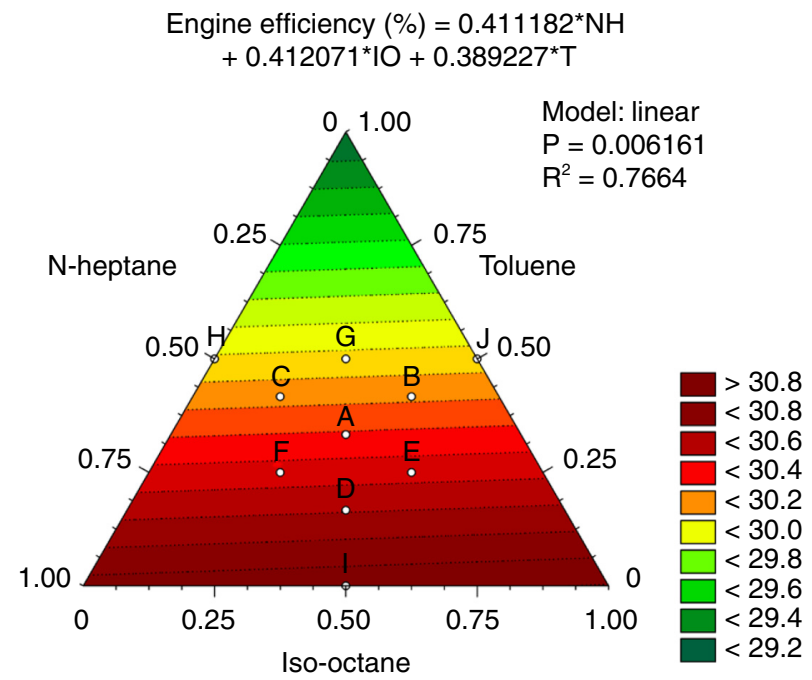

Note: $25 \%$ v/v ethanol

Figure 8

Engine efficiency at $2250 \mathrm{rpm}$ with partial load.

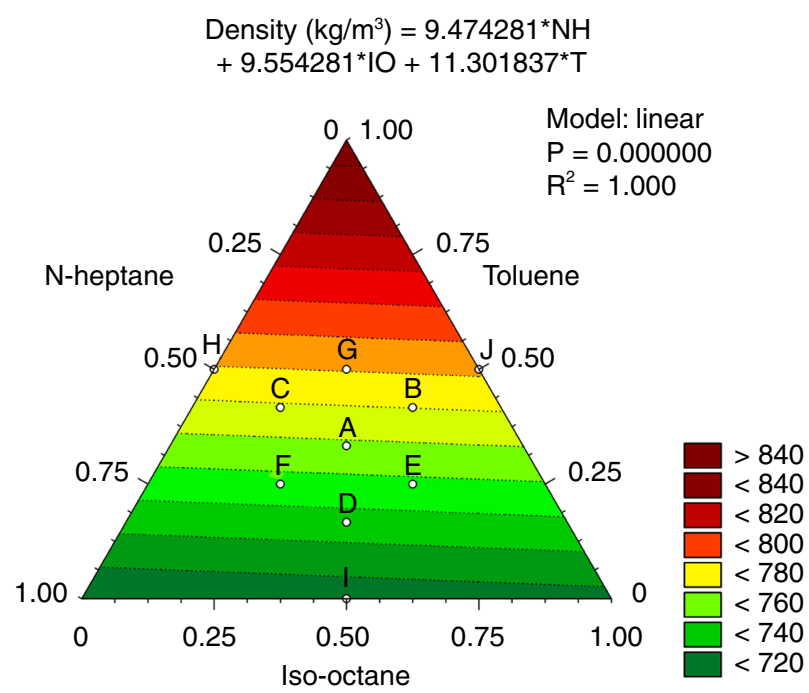

Note: $25 \%$ v/v ethanol

Figure 10

Fuel density.

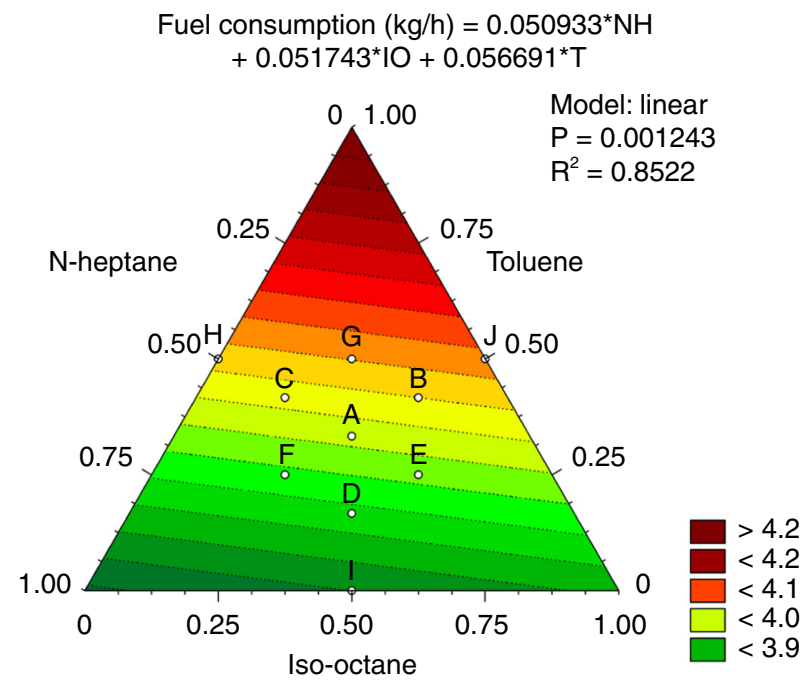

Note: $25 \%$ v/v ethanol

Figure 9

Fuel consumption at $2250 \mathrm{rpm}$ with partial load.

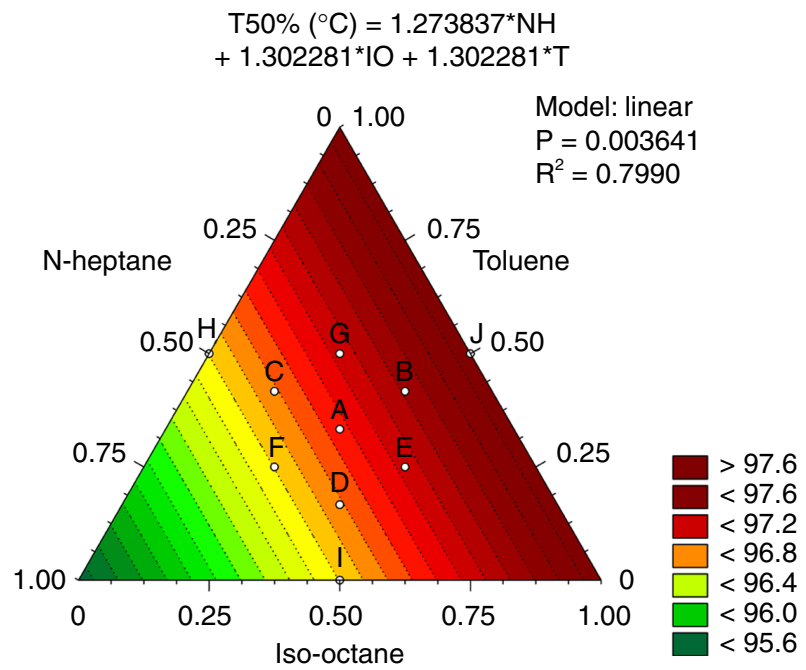

Note: $25 \%$ v/v ethanol

Figure 11

Fuel T50\%.
As expected, the higher the stoichiometric air/fuel ratio is, the lower the fuel consumption is. The fuel consumption had the same tendency for all of the operating conditions tested, as shown in Figures 3 and 9, which represent $3875 \mathrm{rpm}$ with WOT and $2250 \mathrm{rpm}$ with partial load conditions, respectively. Despite the small differences in the stoichiometric air/fuel ratio among the fuels utilized, it was possible to observe the impact on fuel consumption. Figure 4 illustrates the slight asymmetry that can contribute to $n$-heptane being more effective than iso-octane in reducing fuel consumption. The lower density and T50\% values of $n$-heptane, shown in Figures 10 and 11, respectively, help to promote improved vaporization and mixture formation. This behavior can 


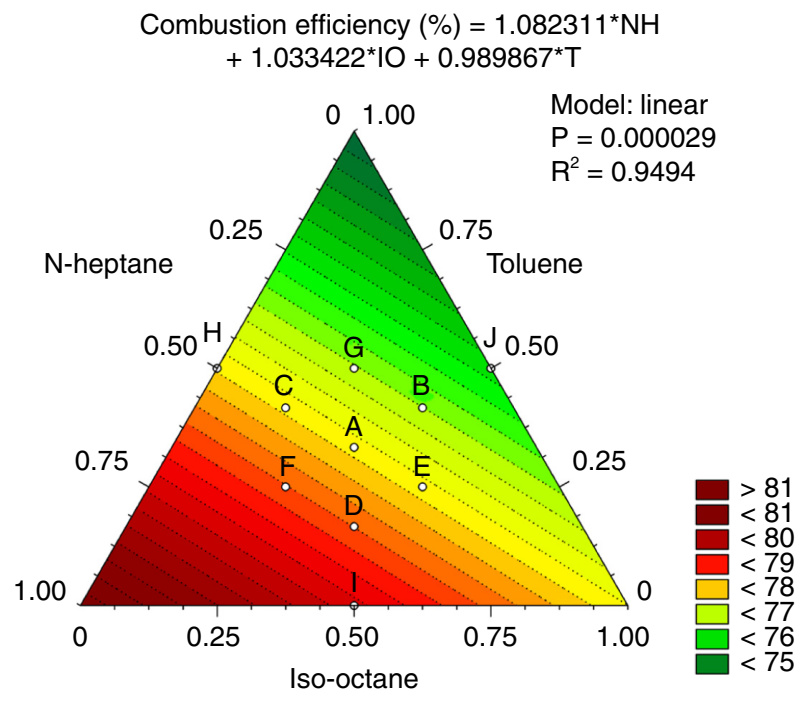

Note: $25 \%$ v/v ethanol

Figure 12

Combustion efficiency at $3875 \mathrm{rpm}$ with WOT.

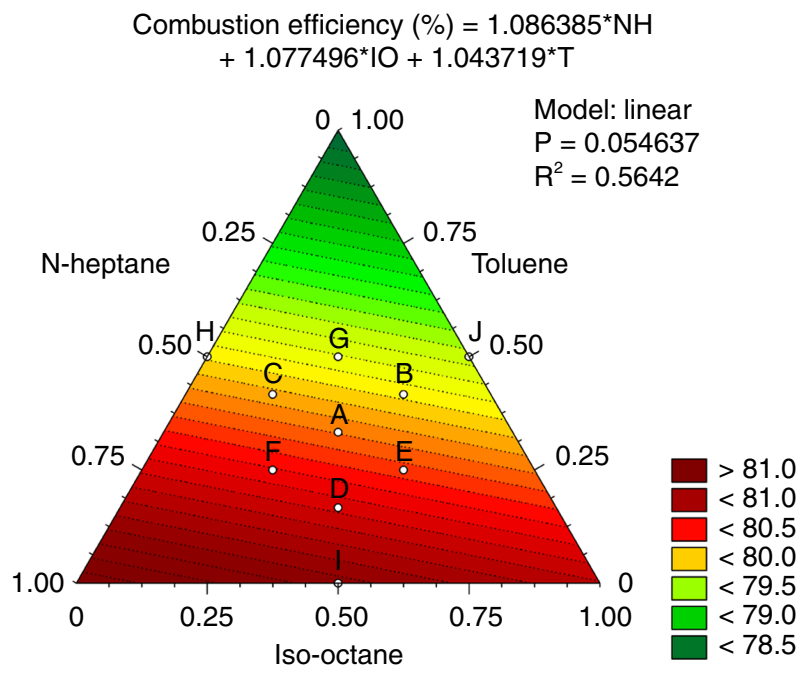

Note: $25 \%$ v/v ethanol

Figure 13

Combustion efficiency at $2250 \mathrm{rpm}$ with partial load. also contribute to making $n$-heptane more effective than iso-octane in reducing fuel consumption.

\subsubsection{Engine Combustion Efficiency}

In this work, the combustion efficiency was defined as the ratio of the net heat release to the energy flow rate delivered to the engine in one cycle (the product of the fuel consumption and fuel lower heating value per cycle). The net heat release was calculated through combustion analysis using the average pressure curve from 300 recorded engine cycles as in Machado (2012). The net heat release excludes the amount of fuel energy transferred to the combustion chamber walls and crevice volumes and is related to the sensible energy change and work transfer to the piston (Heywood, 1988).

The engine combustion efficiency showed the same trends for all of the operating conditions. This is shown for the two examples in Figures 12 and 13, $3875 \mathrm{rpm}$ at WOT and $2250 \mathrm{rpm}$ with partial load, respectively.

The trends show higher efficiencies for the fuels with higher concentrations of $n$-heptane followed by isooctane and toluene. This behavior can be related to the molecular structure of the components. The simpler straight chain of $n$-heptane was easier to burn followed by the branched chain of iso-octane and then the more complex aromatic chain of toluene. For the operating conditions that were not sensitive to knocking, the combustion efficiency trend (Fig. 13) associated with the fuel consumption behavior (Fig. 9) and the LHV per kg of stoichiometric air tendency (Fig. 5) clarifies the improved overall engine efficiency of $n$-heptane and iso-octane in relation to toluene (Fig. 8).

For the operating conditions that were not sensitive to knocking, $n$-heptane is an interesting component, as it simultaneously contributes to a reduction in fuel consumption and an increase in engine combustion and overall engine efficiencies. Iso-octane shows the best compromise. Iso-octane increases the octane rating and the stoichiometric air/fuel ratio contributing to increase engine efficiency for all of the operating conditions, independent of engine knocking susceptibility.

\subsection{Influence of Fuel Components and Properties on Engine Emissions}

This section presents the volumetric emissions results of $\mathrm{CO}_{2}, \mathrm{CO}$ and $\mathrm{HC}$. Then the results of specific emissions are presented in $\mathrm{g} / \mathrm{kWh}$ to compare the different observed trends between these two emissions reporting methods. 


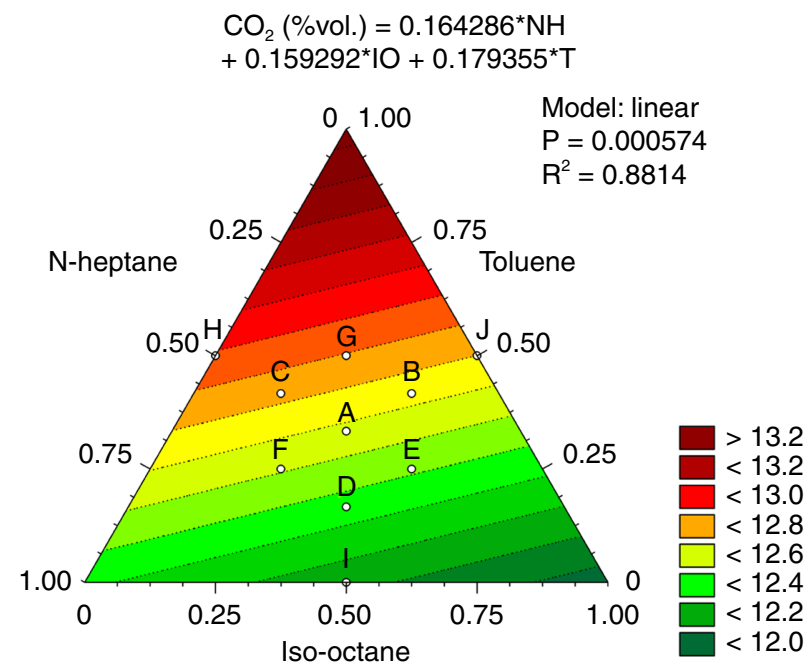

Note: $25 \%$ v/v ethanol

Figure 14

Volumetric emissions of $\mathrm{CO}_{2}$ at $3875 \mathrm{rpm}$ with WOT.

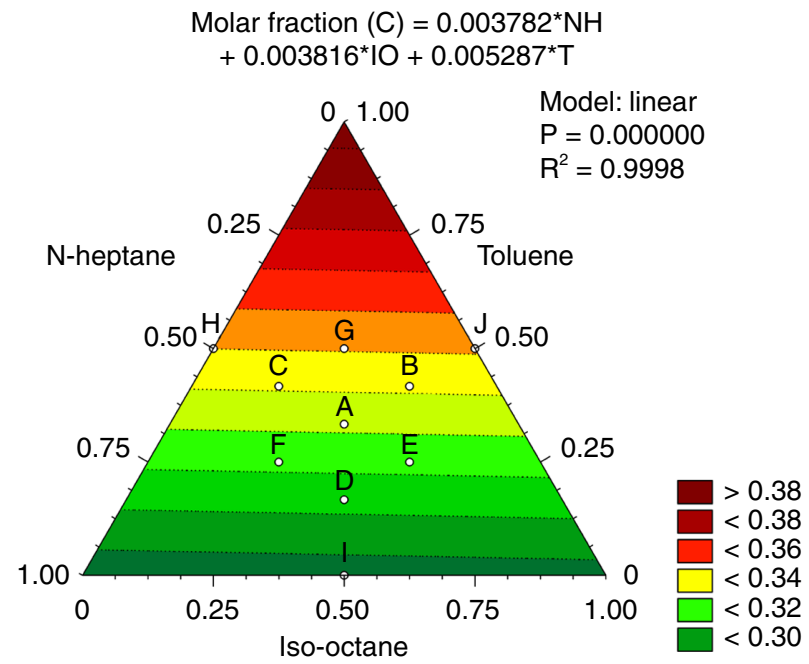

Note: $25 \%$ v/v ethanol

Figure 16

Fuel carbon molar fraction.

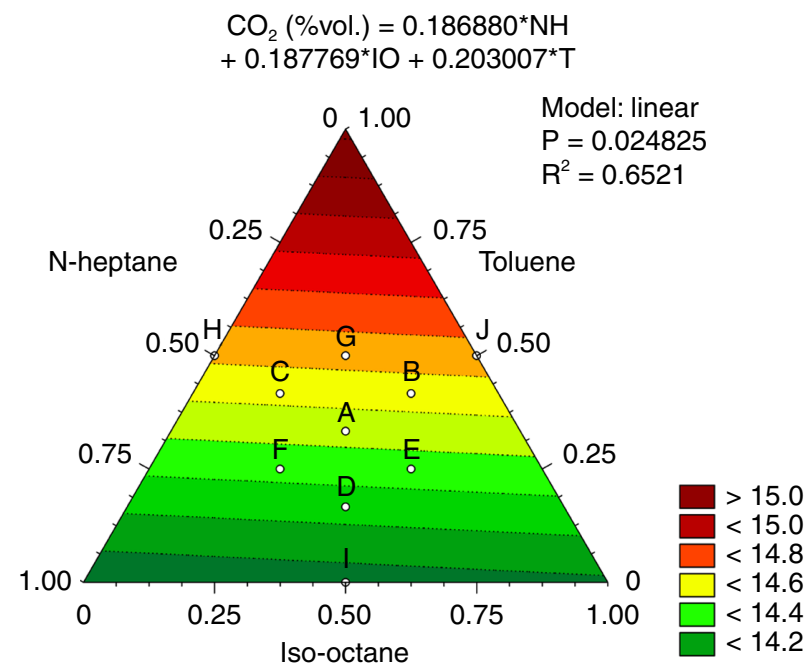

Note: $25 \%$ v/v ethanol

Figure 15

Volumetric emissions of $\mathrm{CO}_{2}$ at $2250 \mathrm{rpm}$ with partial load.

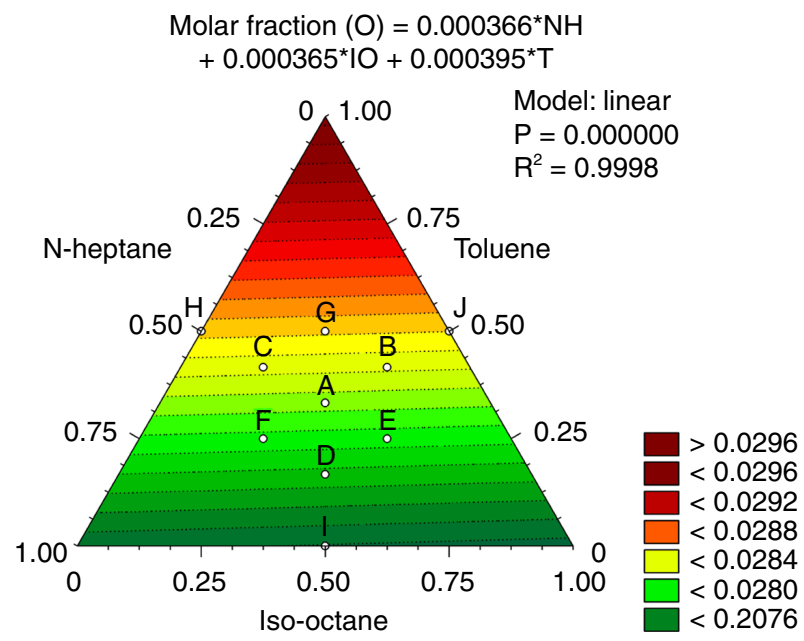

Note: $25 \%$ v/v ethanol

Figure 17

Fuel oxygen molar fraction.

\subsubsection{Volumetric Emissions of Pollutants}

\section{Volumetric Emissions of $\mathrm{CO}_{2}$}

Regarding $\mathrm{CO}_{2}$ emissions, response surface models with similar trends were obtained for all of the operating conditions. Two examples are shown in Figures 14 and 15, and represent $3875 \mathrm{rpm}$ with WOT and $2250 \mathrm{rpm}$ with partial load, respectively.
In general, toluene contributes to increased $\mathrm{CO}_{2}$ emissions, while $n$-heptane and iso-octane reduce $\mathrm{CO}_{2}$ emissions. These trends can be related to the fuel molar fractions of carbon and oxygen (Fig. 16, 17) and to the fuel consumption, which had the same trends for all of the operating conditions (Fig. 3, 9). Higher amounts of toluene contribute to an increase in the fuel carbon and oxygen contents and the fuel consumption, which increases the $\mathrm{CO}_{2}$ emissions. 


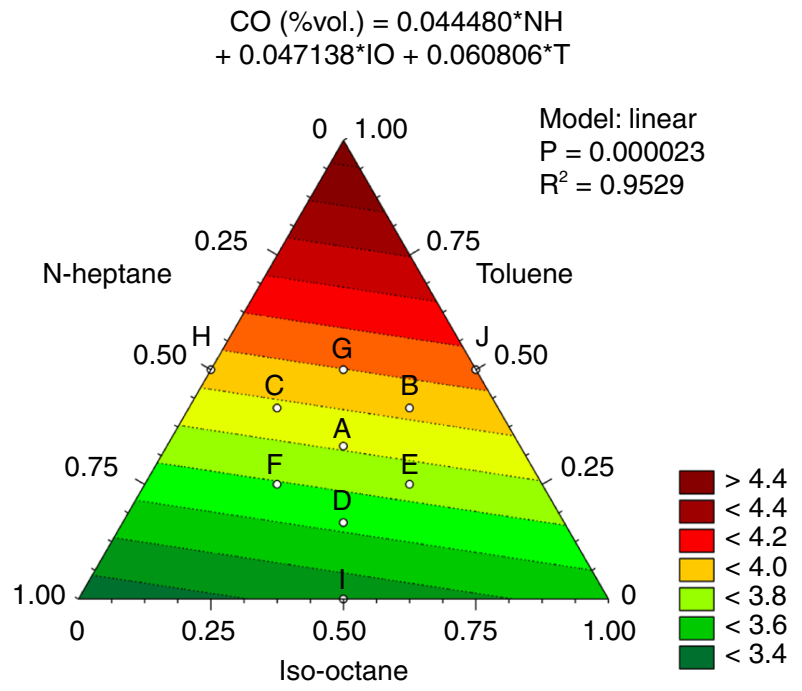

Note: $25 \%$ v/v ethanol

Figure 18

Volumetric emissions of CO at $3875 \mathrm{rpm}$ with WOT.

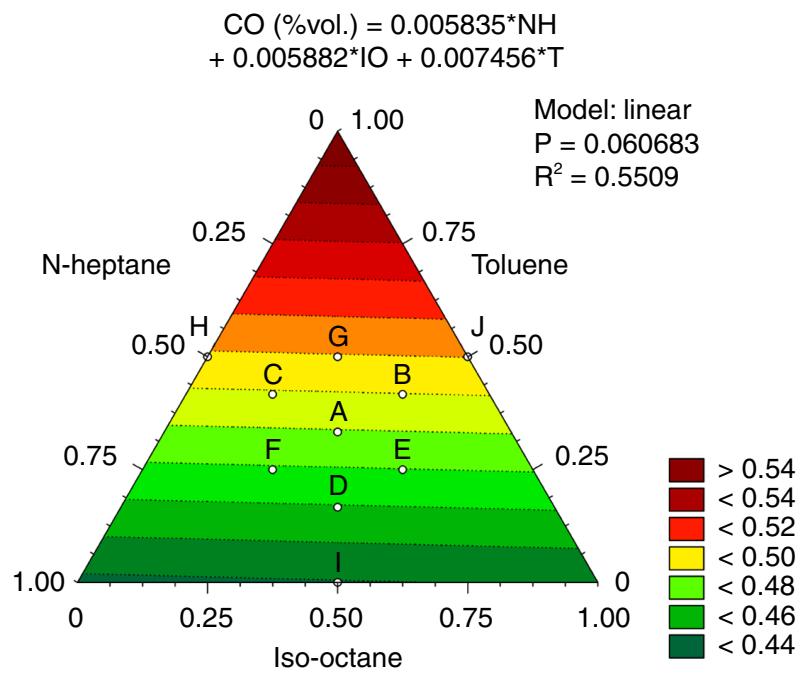

Note: $25 \%$ v/v ethanol

Figure 19

Volumetric emissions of $\mathrm{CO}$ at $2250 \mathrm{rpm}$ with partial load.

\section{Volumetric Emissions of $\mathrm{CO}$}

Statistically significant response surface models of the $\mathrm{CO}$ emissions had similar trends for all of the operating conditions, with the exception of the $1500 \mathrm{rpm}$ with partial load condition. Two examples are shown in Figures 18 and 19 referring respectively to $3875 \mathrm{rpm}$ (WOT) and $2250 \mathrm{rpm}$ (partial load).

In general, the trends are similar to those observed for the $\mathrm{CO}_{2}$ emissions. Higher contents of toluene presented higher levels of $\mathrm{CO}$ emissions. This is related to the contribution of toluene to the increase in the fuel carbon content (Fig. 16) and the increase in the fuel consumption (Fig. 3,9) associated with its contribution to reduce combustion efficiency (Fig. 12,13).

It is important to note that $n$-heptane contributed to a reduction in $\mathrm{CO}$ emissions more effectively than isooctane. This is related to the higher combustion efficiency observed with the higher contents of $n$-heptane. This explains the higher $\mathrm{CO}_{2}$ emissions for fuels with higher $n$-heptane levels compared to the fuels with higher iso-octane levels for the $3875 \mathrm{rpm}$ with WOT operating condition (Fig. 14). The $2250 \mathrm{rpm}$ with partial load condition presented a smaller difference between the $n$-heptane and iso-octane contributions to $\mathrm{CO}$ emissions (Fig. 19). This fact, combined with the lower fuel consumption with larger levels of $n$-heptane (Fig. 9), contributes to a reduction in $n$-heptane $\mathrm{CO}_{2}$ emissions compared to iso-octane at the $2250 \mathrm{rpm}$ with partial load condition (Fig. 15). The carbon and oxygen contents of $n$-heptane and iso-octane are similar (Fig. 16, 17), which plays a minor role in explaining the differences in $\mathrm{CO}$ and $\mathrm{CO}_{2}$ emissions between these components.

\section{Volumetric Emissions of HC}

Statistically significant response surface models of HC emissions were obtained for 3875 and $5500 \mathrm{rpm}$ with WOT as well as for 1500 and $3875 \mathrm{rpm}$ with partial load operating conditions. These trends are shown in Figures 20 and 21 for the $5500 \mathrm{rpm}$ with WOT and $1500 \mathrm{rpm}$ with partial load operating conditions, respectively. Despite the low $R^{2}$ values, the similar trends for all of the different operating conditions that presented statistically significant models support the analyses.

Fuels with higher contents of iso-octane contribute to an increase in $\mathrm{HC}$ emissions, while higher contents of $n$-heptane reduce $\mathrm{HC}$ emissions. In this case, the molar fractions of carbon, oxygen and hydrogen, observed in Figures 16, 17 and 22, respectively, do not influence this behavior, as they are similar for iso-octane and $n$-heptane.

Again, the higher combustion efficiency of the fuels with higher contents of $n$-heptane (Fig. 12, 13) favors the reduction of $\mathrm{HC}$ emissions. The differences in $\mathrm{HC}$ emission trends between iso-octane and toluene can be 


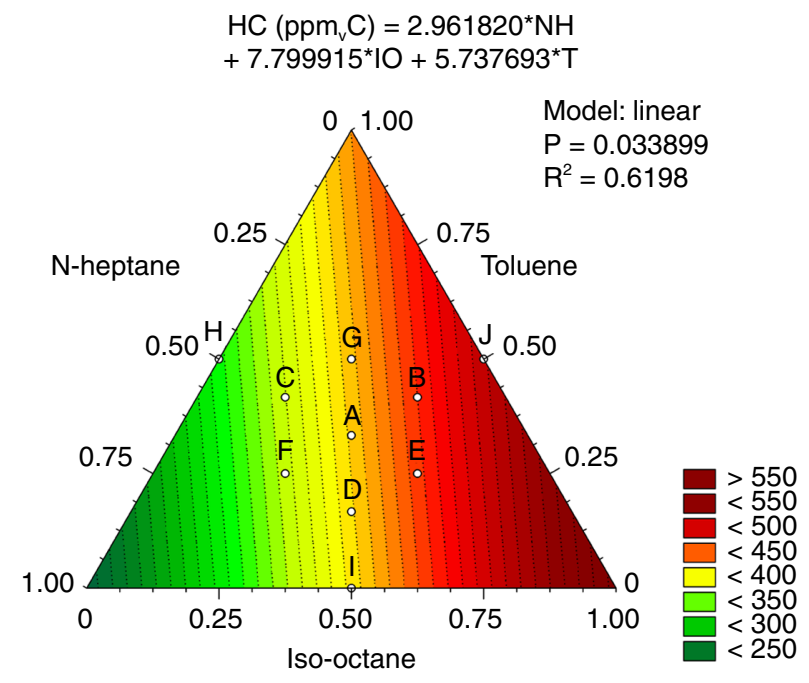

Note: $25 \%$ v/v ethanol

Figure 20

Volumetric emissions of $\mathrm{HC}$ at $5500 \mathrm{rpm}$ with WOT.

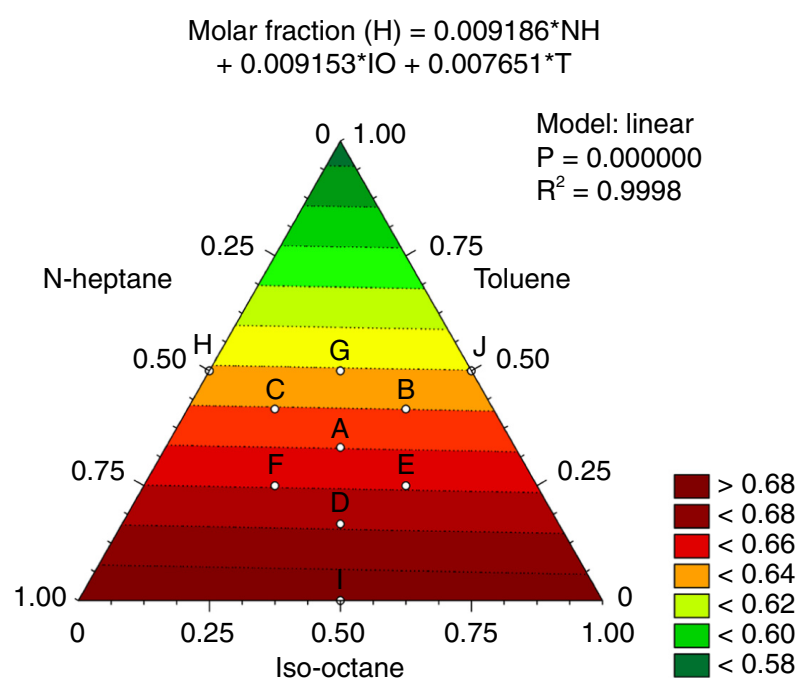

Note: $25 \%$ v/v ethanol

Figure 22

Fuel hydrogen molar fraction.

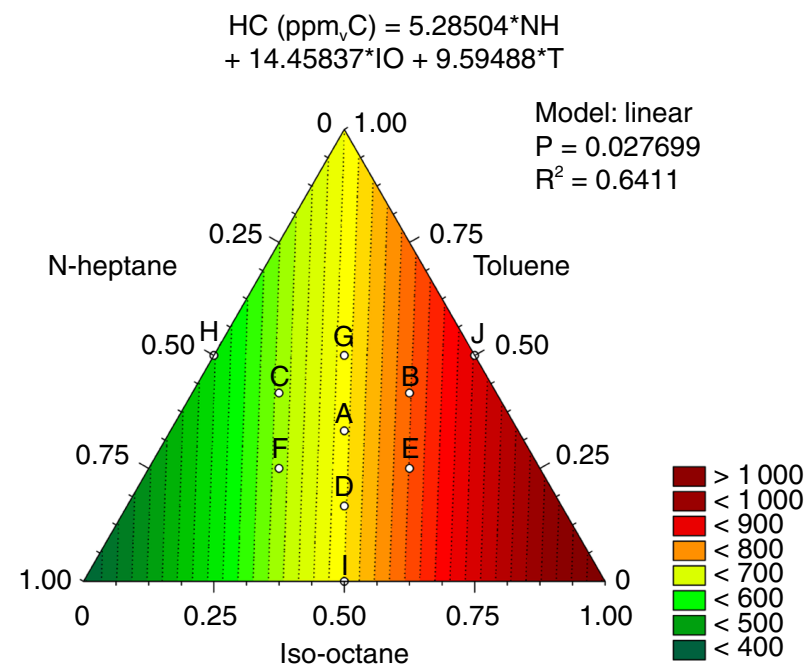

Note: $25 \%$ v/v ethanol

Figure 21

Volumetric emissions of $\mathrm{HC}$ at $1500 \mathrm{rpm}$ with partial load.

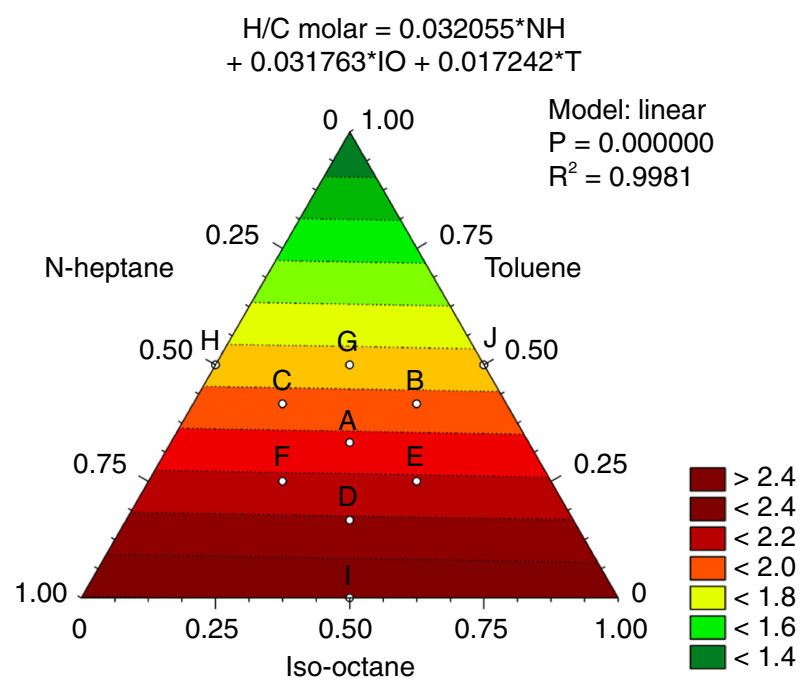

Note: $25 \% \mathrm{v} / \mathrm{v}$ ethanol

Figure 23

Fuel $\mathrm{H} / \mathrm{C}$ molar ratio. tied to the higher molar fractions of hydrogen and the higher $\mathrm{H} / \mathrm{C}$ molar ratio of the fuels containing higher levels of iso-octane. This is shown in Figures 22 and 23. The availability of hydrogen atoms and the combustion efficiency directly influence the diffusion of fuel into the lubricating oil layer on the cylinder walls and the crevice volumes. These are the primary mechanisms of HC emissions in the engines (Heywood, 1988). 
It is important to note that the higher molecular weight of iso-octane, compared to the other components, favors fuel absorption into the lubricating oil layer on the cylinder walls. Fuel solubility is a positive function of the molecular weight; therefore, the oil layer contributes to $\mathrm{HC}$ emissions depending on the solubility of different individual hydrocarbons in the lubricating oil. In fact, during compression the fuel vapor pressure increases and, according to Henry's law, absorption occurs even if the oil was saturated during intake. During combustion, the fuel vapor concentration in the burned gases goes to zero. Therefore, the absorbed fuel vapor will desorb from the liquid oil into the burned gases when the cylinder pressure decreases in the expansion stroke. By this time, complete combustion can no longer take place (AVL, 2011).

\section{Comments Regarding the Volumetric Emissions Results}

In the present case, as the engine running points have been made in terms of $\%$ throttle position and not at a constant torque for instance, there is an interest in the volumetric emissions measurement. There are also engine applications where the volumetric emissions of pollutants are regulated. The analysis demonstrated that $n$-heptane was more effective in reducing the volumetric emissions. $N$-heptane can be an interesting component in cases where the volumetric emissions are regulated. In general, the molecular structure of the different fuels and the combustion efficiency presented a major impact on the trends observed for the volumetric emissions for all of the operating conditions. This behavior is due to the fact that all of the operating conditions, both those sensitive and those not sensitive to knocking, presented similar trends for volumetric emissions and showed similar combustion efficiency trends.

\subsubsection{Specific Emissions in $\mathrm{g} / \mathrm{kWh}$}

It is interesting to note that the specific emissions measured in $\mathrm{g} / \mathrm{kWh}$ show different trends, due to the more significant impact of engine fuel consumption and engine power. This phenomenon will be shown in more detail in the next sections.

\section{$\mathrm{CO}_{2}$ Specific Emissions in $\mathrm{g} / \mathrm{kWh}$}

For the operating conditions that are sensitive to knocking, the $\mathrm{CO}_{2}$ specific emissions are exemplified with $3875 \mathrm{rpm}$ at WOT shown in Figure 24. Higher levels of $n$-heptane increased the $\mathrm{CO}_{2}$ specific emissions. This phenomenon is explained by the reduced engine

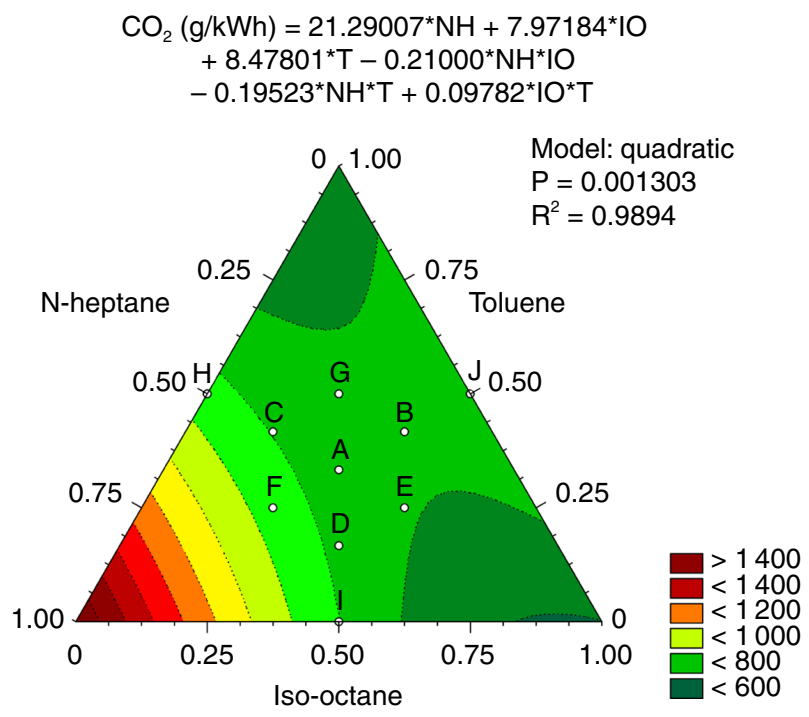

Note: $25 \%$ v/v ethanol

Figure 24

$\mathrm{CO}_{2}$ specific emissions in $\mathrm{g} / \mathrm{kWh}$ at $3875 \mathrm{rpm}$ with WOT.

torque (and power) that occurs with increasing $n$-heptane levels (Fig. 2), because it was not possible to optimize spark timing at Maximum Brake Torque (MBT) in the presence of knocking (Fig. 7).

The tendency toward lower volumetric emissions, combined with the tendency toward higher torque using fuels with higher iso-octane levels than toluene (Fig. 14, 2), favors the iso-octane. This component presented lower levels of $\mathrm{CO}_{2}$ specific emissions than toluene.

For the operating conditions that are not sensitive to knocking, the $\mathrm{CO}_{2}$ specific emissions are exemplified with $2250 \mathrm{rpm}$ at partial load shown in Figure 25. The lower fuel consumption (Fig. 9) favors fuels with higher levels of $n$-heptane. This component contributed to the lowest levels of $\mathrm{CO}_{2}$ specific emissions. For the $\mathrm{CO}_{2}$ specific emissions results (Fig. 25), $n$-heptane is followed by iso-octane then toluene, maintaining the same trend observed for the volumetric emissions (Fig. 15) and the fuel consumption. This result occurred because for these operating conditions, there were not significant differences in the engine torque (and power) delivered with the different fuels.

\section{CO Specific Emissions in $\mathrm{g} / \mathrm{kWh}$}

The trends for $\mathrm{CO}$ specific emissions were similar to those observed for $\mathrm{CO}_{2}$. For the conditions that are sensitive to knocking, the $\mathrm{CO}$ specific emissions are 


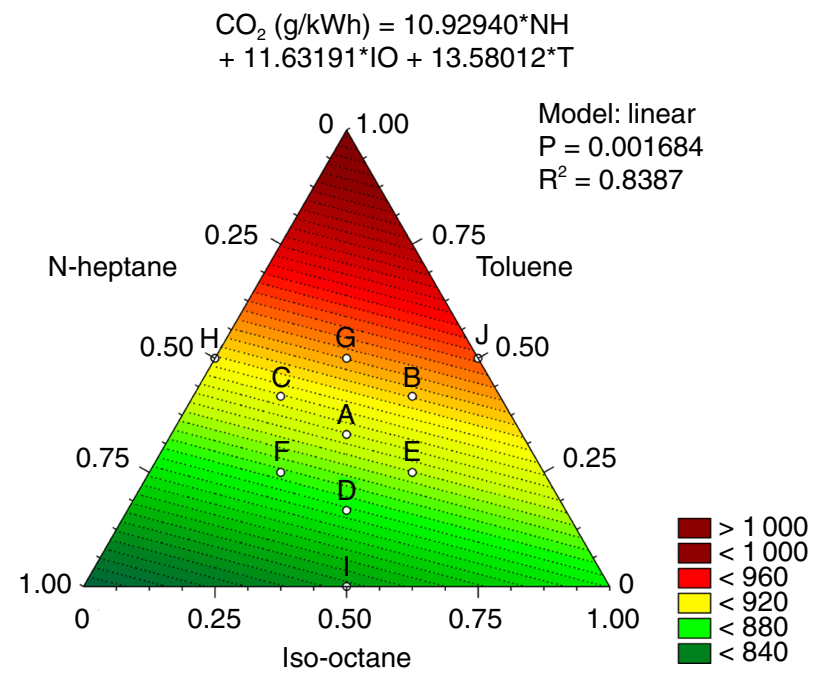

Note: $25 \%$ v/v ethanol

Figure 25

$\mathrm{CO}_{2}$ specific emissions in $\mathrm{g} / \mathrm{kWh}$ at $2250 \mathrm{rpm}$ with partial load.

exemplified with $3875 \mathrm{rpm}$ at WOT shown in Figure 26. Higher $n$-heptane levels increased the emissions as a result of the lower engine torque (and power) delivered (Fig. 2). The trends for lower volumetric emissions (Fig. 18) and the trends for higher torques using fuels with higher iso-octane levels than toluene (Fig. 2) favor the iso-octane. This component presented lower levels of $\mathrm{CO}$ specific emissions than toluene.

For the operating conditions that are not sensitive to knocking, the $\mathrm{CO}$ specific emissions are exemplified with $2250 \mathrm{rpm}$ at partial load shown in Figure 27. The lower fuel consumption observed for higher levels of $n$-heptane (Fig. 9) favors the lower CO specific emissions. For the specific emissions results (Fig. 27), $n$-heptane is followed by iso-octane then toluene, maintaining the same trend observed for the volumetric emissions (Fig. 19) and the fuel consumption. This result occurred because for these operating conditions, there were not significant differences in the engine torque (and power) delivered with the different fuels.

\section{HC Specific Emissions in $\mathrm{g} / \mathrm{kWh}$}

The trends observed for the $\mathrm{HC}$ volumetric emissions were maintained in $\mathrm{g} / \mathrm{kWh}$ for the conditions evaluated. This is shown for the $5500 \mathrm{rpm}$ with WOT condition in Figure 28 compared to Figure 20. This behavior is explained by the larger differences observed for the

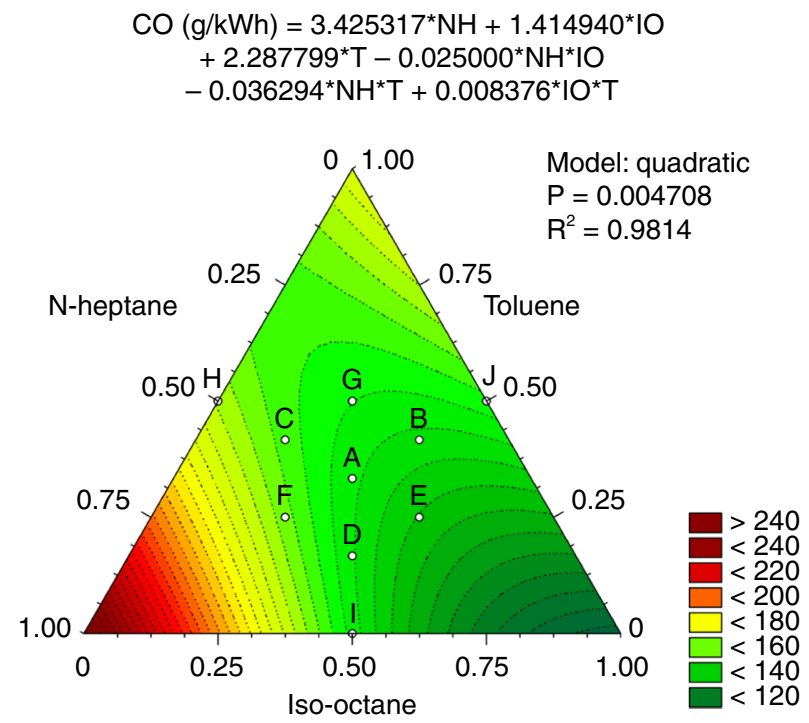

Note: $25 \%$ v/v ethanol

Figure 26

CO specific emissions in $\mathrm{g} / \mathrm{kWh}$ at $3875 \mathrm{rpm}$ with WOT.

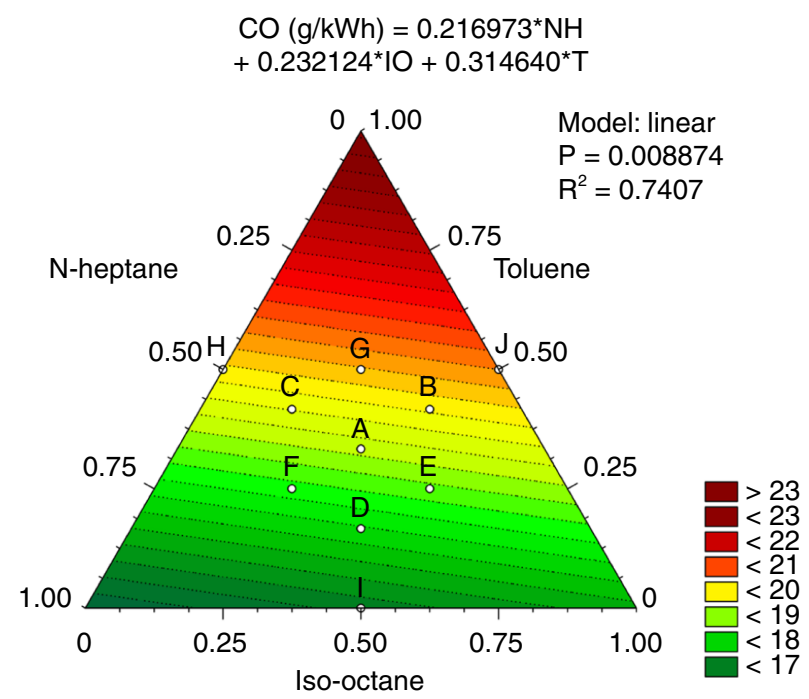

Note: $25 \% \mathrm{v} / \mathrm{v}$ ethanol

Figure 27

$\mathrm{CO}$ specific emissions in $\mathrm{g} / \mathrm{kWh}$ at $2250 \mathrm{rpm}$ with partial load.

volumetric emissions of $\mathrm{HC}$ among the different fuels tested, which had the primary impact on the specific emissions rather than the torque and fuel consumption differences. The molecular structure of the different fuels 


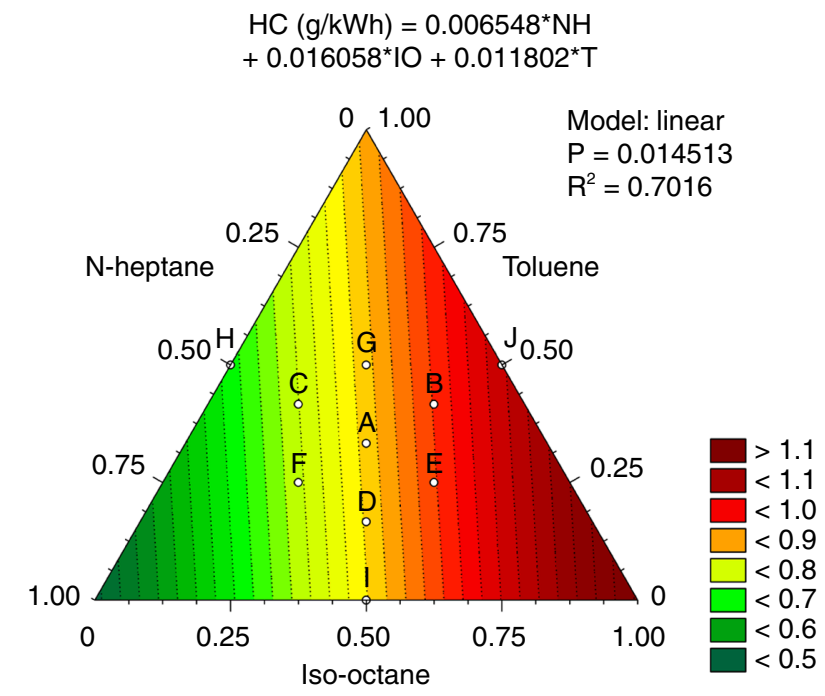

Note: $25 \%$ v/v ethanol

Figure 28

HC specific emissions in $\mathrm{g} / \mathrm{kWh}$ at $5500 \mathrm{rpm}$ with WOT.

and the combustion efficiency had a major impact on $\mathrm{HC}$ emissions.

\section{CONCLUSIONS}

The analyses presented in this work show that surrogate fuels can be utilized to investigate fuel components and study their influences on fuel properties and engine combustion, performance and emissions.

Based on the results obtained, $n$-heptane can be an interesting component for fuels destined for special applications that are not sensitive to knocking. This component improves the engine combustion efficiency and overall engine efficiency, reducing $\mathrm{CO}$ and $\mathrm{HC}$ emissions without significantly increasing the levels of $\mathrm{CO}_{2}$ emissions. The amount of this component in the fuel will depend on the engine type and its octane rating requirement. Engines with a low compression ratio and stationary engines operating in conditions that are not sensitive to knocking can be favorably affected by the use of higher amounts of $n$-heptane. Applications with high engine speeds, where there is no time available for knocking to occur, such as motorcycle and racing engines, could use higher amounts of $n$-heptane in the fuel.

For applications with a high octane rating requirement, such as high compression ratio engines, toluene and iso-octane are important components for improving engine performance and reducing $\mathrm{CO}_{2}$ and $\mathrm{CO}$ specific emissions. Iso-octane can be more useful as it contributes to higher engine combustion efficiency, higher overall engine efficiency and lower levels of $\mathrm{CO}_{2}$ and $\mathrm{CO}$ emissions than toluene. However, toluene presented lower $\mathrm{HC}$ emissions than iso-octane.

Iso-octane is an interesting and versatile component. It increases the octane rating and the stoichiometric air/fuel ratio, and helps to increase engine efficiency for all operating conditions independent of knocking susceptibility. It also contributes to the reduction of $\mathrm{CO}_{2}$ and $\mathrm{CO}$ specific emissions, despite the increase observed in $\mathrm{HC}$ emissions. The iso-octane branched chain favors the good compromise observed for this component.

It is clear that there is a compromise among several engine combustion, performance and emission parameters. It is important to verify the relative importance of each parameter as a function of the engine type and its application to select a more adequate and efficient fuel.

In general, the trends and conclusions observed for the different components utilized could be extended for the chemical group they represent (n-paraffins, isoparaffins and aromatics). This fact can help to select the fuel components and refinery processing streams to be used in fuel formulation for different applications. $\mathrm{N}$-paraffins are common in naphthas from atmospheric distillation. Iso-paraffins are present at high concentrations in the products from the processes of alkylation and isomerization, while the aromatics are present in high concentrations in the products of catalytic reforming. This prior selection of components and processing streams can reduce the number of experimental tests, and reduce cost and time involved in the fuel development processes.

The approach introduced in this paper can also be used to investigate the influence of other fuel components, including renewable fuels, and refinery processing streams on fuel properties and engine performance. The results presented put together information and methodologies that can be used in fuel development processes for different applications.

\section{REFERENCES}

Andrae J.C.G. (2008) Development of a detailed kinetic model for gasoline surrogate fuels, Fuel 87, 10-11, 2013-2022.

ANP (2011) Brazilian National Petroleum, Natural Gas and Biofuels Agency, ANP Resolution \# 57 - Regulation for Brazilian automotive gasoline specification, ANP, Brazil.

AVL (2011) BOOST software, version 2011 - Theory, AVL, Graz, Austria. 
Berta P., Aggarwal S.K., Puri I.K. (2006) An experimental and numerical investigation of $n$-heptane/air counterflow partially premixed flames and emission of NOx and PAH species, Combust. Flame 145, 4, 740-764.

Bounaceur R., Costa I.D., Fournet R., Billaud F., BattinLeclerc F. (2005) Experimental and modeling study of the oxidation of toluene, Int. J. Chem. Kinet. 37, 1, 25-49.

Calado V.M.A., Montgomery D.C. (2003) Design of Experiments using Statistica, E-papers, Rio de Janeiro, Brazil.

CFR (2009) Code of Federal Regulations, CFR Title 40 Part 91 - Control of emissions from marine spark-ignition engines, Subpart E-Gaseous exhaust test procedures, CFR, USA.

Curran H.J., Gaffuri P., Pitz W.J., Westbrook C.K. (1998) A comprehensive modeling study of $n$-heptane oxidation, Combust. Flame 114, 1-2, 149-177.

Curran H.J., Gaffuri P., Pitz W.J., Westbrook C.K. (2002) A comprehensive modeling study of iso-octane oxidation, Combust. Flame 129, 253-280.

Dagaut P., Pengloan G., Ristori A. (2002) Oxidation, ignition and combustion of toluene: Experimental and detailed chemical kinetic modeling, Phys. Chem. Chem. Phys. 4, 10, 18461854.

Davidson D.F., Gauthier B.M., Hanson R.K. (2005) Shock tube ignition measurements of iso-octane/air and toluene/air at high pressures, Proc. Combust. Inst. 30, 1, 1175-1182.

Emdee J.L., Brezinsky K., Glassman I. (1992) A kinetic-model for the oxidation of toluene near 1200-K, J. Phys. Chem. 96, 5, 2151-2161.

Gauthier B.M., Davidson D.F., Hanson R.K. (2004) Shock tube determination of ignition delay times in full blend and surrogate fuel mixtures, Combust. Flame 139, 4, 300-311.

Herzler J., Jerig L., Roth P. (2005) Shock tube study of the ignition of lean $n$-heptane/air mixtures at intermediate temperatures and high pressures, Proc. Combust. Inst. 30, 1, 11471153.

He X., Donovan M.T., Zigler B.T., Palmer T.R., Walton S.M., Wooldridge M.S., Atreya A. (2005) An experimental and modeling study of iso-octane ignition delay times under homogeneous charge compression ignition conditions, Combust. Flame 142, 3, 266-275.

Heywood J.B. (1988) Internal Combustion Engine Fundamentals, McGraw Hill Inc., USA.
ISO (1992) International Organization for Standardization, ISO 1585 - Road vehicles, engine test code, net power, ISO, Geneva, Switzerland.

Machado G.B. (2012) Metodologias para Desenvolvimento de Combustiveis e Determinação da Velocidade de Propagação de Chama em Motores de Ignição por Centelha, PhD Thesis, Pontifícia Universidade Católica do Rio de Janeiro - PUCRio, Rio de Janeiro, Brazil.

Machado G.B., Barros J.E.M., Braga S.L., Braga C.V.M., Oliveira E.J., Silva A.H.M.F.T., Carvalho L.O. (2011) Investigations on surrogate fuels for high octane oxygenated gasolines, Fuel 90, 2, 640-646.

Machado G.B., Barros J.E.M., Braga S.L., Braga C.V.M., Oliveira E.J., Silva A.H.M.F.T., Azevedo E.C.Z. (2012) Methodologies for fuel development using surrogate fuels on spark ignition engines, SAE Technical Paper 2012-36-0477.

Melo T.C.C., Machado G.B., Belchior C.R.P., Colaço M.J., Barros J.E.M., Oliveira E.J., Oliveira D.G. (2012) Hydrous ethanol-gasoline blends - combustion and emission investigation on a flex-fuel engine, Fuel 97, 796-804.

Montgomery D.C., Runger G.C. (1994) Applied Statistics and Probability for Engineers, John Wiley \& Sons, New York, USA.

Pitz W.J., Seiser R., Bozzelli J.W., Seshadri K., Chen C.J., Costa I.D., Fournet R., Billaud F., Battin-Leclerc F., Westbrook C.K. (2003) Chemical Kinetic Study of Toluene Oxidation under Premixed and Nonpremixed Conditions, UCRL-CONF-201575, Lawrence Livermore National Laboratory, California, USA.

Pitz W.J., Cernansky N.P., Dryer F.L., Egolfopoulos F.N., Farrell J.T., Friend D.G., Pitsch H. (2007) Development of an experimental database and chemical kinetic models for surrogate gasoline fuels, SAE Technical Paper 2007-01-0175.

Silke E.J., Curran H.J., Simmie J.M. (2005) The influence of fuel structure on combustion as demonstrated by the isomers of heptane: a rapid compression machine study, Proc. Combust. Inst. 30, 2, 2639-2647.

Sivaramakrishnan R., Tranter R.S., Brezinsky K. (2005) A high pressure model for the oxidation of toluene, Proc. Combust. Inst. 30, 1, 1165-1173.

Manuscript accepted in August 2013 Published online in February 2014

Cite this article as: G.B. Machado, J.E.M. Barros, S.L. Braga, C.V.M. Braga, A.H.M. da F.T. da Silva and E.C.Z. de Azevedo (2014). Influence of Gasoline Components on Engine Efficiency and Emissions, Oil Gas Sci. Technol 71, 12. 